\title{
Relative concentration of 13,14-dihydro-15 keto- prostaglandin $F-2 \alpha$ in blood and milk of buffaloes during the oestrous cycle and early pregnancy
}

\author{
S. K. Batra and R. S. Pandey \\ Hormone Research Laboratory, Dairy Chemistry Division, National Dairy Research Institute, \\ Karnal 132001 (Haryana), India
}

\begin{abstract}
Summary. Concentrations of PGFM in blood and milk of 28 Murrah buffaloes increased significantly $(P<0.001)$ in non-pregnant animals before oestrus but not in pregnant animals. The PGFM level in milk was similar to that in blood plasma and was positively correlated in non-pregnant $(r=0.981)$ and pregnant $(r=0.521)$ animals. Mean blood plasma PGFM concentration was not significantly $(P<0.05)$ different from that of milk.
\end{abstract}

\section{Introduction}

Prostaglandin (PG) F-2 $\alpha$ is known to play an important role in ovarian function of dairy cows (Louis, Hafs \& Morrow, 1972; Rowson, Tervit \& Brand, 1972; Lamond, Tomilson, Drost, Henricks \& Jochle, 1973) and buffaloes (Bachlaus, Arora, Prasad \& Pandey, 1979; Kamonpatana, Kunawongkrit, Bodhipaksha \& Luvira, 1979). However, the measurement of PGF- $2 \alpha$ released from the uterus is difficult because of the need to cannulate the utero-ovarian blood vessels. To avoid these difficulties, attempts have been made to measure concentrations of PGF- $2 \alpha$ in peripheral blood plasma (Caldwell, Tillson, Brock \& Speroff, 1972) but direct measurement is hindered because of the rapid metabolism of PGs (Granstrom, 1972). Furthermore, the estimations of PGF- $2 \alpha$ are complicated by the possibility of platelet synthesis of PGF- $2 \alpha$ during collection and handling of blood samples (Samuelsson, 1972).

The major metabolite of PGF-2 $\alpha$ in the blood of cows is 13,14-dihydro-15 keto-prostaglandin F$2 \alpha$ (PGFM) (Peterson, Fairclough, Payne \& Smith, 1975; Kindahl, Edqvist, Bane \& Granstrom, 1976a). The concentrations of progesterone in milk have been shown to reflect those in the blood in cows (Dobson, Midmer \& Fitzpatrick, 1975) and buffaloes (Batra, Arora, Bachlaus \& Pandey (1979) and we have therefore studied the concentrations of PGFM in blood and milk during the oestrous cycle and early pregnancy in buffaloes.

\section{Materials and Methods}

Animals and sampling. Twenty-eight Murrah buffaloes (11 primiparous and 17 multiparous) were selected from the Institute herd. They were maintained under general herd management conditions of feeding and loose housing. Oestrus was detected by behavioural symptoms of the cow and the response of the teaser bull. Blood samples were taken by jugular venepuncture from Day 0 (day of insemination) to Day 5 daily, followed by collection on alternate days until Day 15. Daily samples 
were again taken until Day 25 or return to oestrus, whichever occurred earlier. Blood samples were taken on alternate days until Day $\mathbf{4 0}$ of pregnancy for animals that did not return to oestrus. In another group, 6 cyclic buffaloes with known oestrous cycle lengths (not inseminated at the previous oestrus) were sampled at 6-h intervals from 4 days before the expected oestrus. Blood samples were collected rapidly into precooled tubes and centrifuged immediately at $4^{\circ} \mathrm{C}$. The plasma was stored at $-20^{\circ} \mathrm{C}$ until analysis.

Pooled milk samples from the bulk yield of individual animals were collected at the evening milking $(18: 00-20: 00 \mathrm{~h})$ on the same schedule as blood was collected. The samples were preserved with $0.01 \%$ formalin and stored at $4^{\circ} \mathrm{C}$ until analysed.

Radioimmunoassay. PGFM concentration was determined by a modification of radioimmunoassay technique of Manns (1975). The antiserum was raised in rabbits against a PGFM-BSA conjugate. Duplicate milk samples $(200 \mu \mathrm{l})$ were extracted with $2 \mathrm{ml}$ petroleum ether (b.p. $\left.40-60^{\circ} \mathrm{C}\right)$ for $30 \mathrm{sec}$. The lower aqueous phase was frozen and the upper organic phase was discarded. The aqueous phase was thawed and acidified with $1 \mathrm{~N}-\mathrm{HCl}$ to $\mathrm{pH} 3-4$. The samples were again extracted for PGFM with distilled diethyl ether $(2 \mathrm{ml})$ and the extract was evaporated to dryness under nitrogen. The residue was dissolved in $80 \%$ methanol $(2 \mathrm{ml})$ and incubated at $40^{\circ} \mathrm{C}$ for $1 \mathrm{~h}$. The excess fat precipitated by this step was separated by centrifugation at $2600 \mathrm{~g}$ for $20 \mathrm{~min}$ at $-10^{\circ} \mathrm{C}$. The supernatant was decanted and evaporated to dryness. The residue was dissolved in $100 \mu \mathrm{l}$ phosphate-buffered saline (PBS; $0.1 \mathrm{M}$-phosphate buffer $\mathrm{pH} 7.0$ containing $0.15 \mathrm{M}$-sodium chloride, $0.015 \mathrm{M}$-sodium azide and $0.1 \%$ gelatin in distilled water) by maintenance at $45^{\circ} \mathrm{C}$ for $15 \mathrm{~min}$ and vortexing for $30 \mathrm{sec}$ to ensure complete solubility. The resulting mixture was combined with $100 \mu \mathrm{l}$ PGFM antiserum (1 :5000 dilution) and $100 \mu \mathrm{l}\left[5,6,8,9,11,12,14(\mathrm{n}){ }^{3} \mathrm{H}\right] \mathrm{PGFM}(4000$ c.p.m./tube; sp. act. $80 \mathrm{Ci} / \mathrm{mmol}$; Radiochemical Centre, Amersham, U.K.). The mixture was vortexed and incubated at $4^{\circ} \mathrm{C}$ overnight. The bound and unbound fractions were separated by the addition of $500 \mu \mathrm{l}$ dextran-coated charcoal $(1 \%$ activated charcoal Norit A, Sigma Chemical Company, St Louis, U.S.A.; $0.25 \%$ dextran T-70, Pharmacia Company, Uppsala, Sweden). The contents of the tubes were shaken and allowed to equilibrate for $10 \mathrm{~min}$ and centrifuged at $2600 \mathrm{~g}$ for $10 \mathrm{~min}$ at $4^{\circ} \mathrm{C}$. The supernatant containing antiserum bound to PGFM was decanted into scintillation vials containing $10 \mathrm{ml}$ Triton-toluene scintillation fluid ( $7 \mathrm{~g}$ PPO, $0.3 \mathrm{~g}$ POPOP, $60 \mathrm{~g}$ naphthalene, 333 $\mathrm{ml}$ Triton X-100 and $666 \mathrm{ml}$ toluene). The radioactivity was counted after $8 \mathrm{~h}$ equilibration between liquid and organic phase. A series of PGFM standards (Ono Pharmaceutical Company, Osaka, Japan) ranging from 2.5 to $1280 \mathrm{pg}$ in $100 \mu \mathrm{l}$ PBS were concurrently reacted to prepare the standard curve.

PGFM in blood plasma was estimated by extracting a $100 \mu$ sample (acidified to $\mathrm{pH} 3-4$ with 1 $\mathrm{N}-\mathrm{HCl}$ ) with $2 \mathrm{ml}$ diethyl ether. The ether was evaporated to dryness under nitrogen and the residue dissolved in $100 \mu \mathrm{l}$ PBS. The remaining procedure was similar to the milk PGFM assay as described above.

The recovery of PGFM added to plasma and milk was calculated after allowance for procedural losses and subtraction of the endogenous level (Table 1$)$. The average recovery of $\left[{ }^{3} \mathrm{H}\right] \mathrm{PGFM}(4000$

Table 1. Recovery of unlabelled PGFM added to blood plasma and milk (8 replicates)

\begin{tabular}{|c|c|c|c|c|c|c|}
\hline \multirow{2}{*}{$\begin{array}{l}\text { Amount } \\
\text { added } \\
(\mathrm{pg})\end{array}$} & \multicolumn{2}{|c|}{ Amount recovered $(\mathrm{pg})$} & \multicolumn{2}{|c|}{$\%$ Recovery } & \multicolumn{2}{|c|}{ Coefficient of variation } \\
\hline & Blood plasma & Milk & Blood plasma & Milk & Blood plasma & Milk \\
\hline 50 & $50 \cdot 5 \pm 1 \cdot 7$ & $49 \cdot 1 \pm 1 \cdot 5$ & $108 \cdot 1 \pm 3 \cdot 3$ & $98 \cdot 2 \pm 3 \cdot 1$ & $8 \cdot 7$ & 8.9 \\
\hline 100 & $105 \cdot 5 \pm 3 \cdot 3$ & $99.9 \pm 2.8$ & $105 \cdot 6 \pm 3 \cdot 3$ & $99.9 \pm 2.8$ & 8.9 & $7 \cdot 9$ \\
\hline 200 & $206 \cdot 2 \pm 3 \cdot 0$ & $196 \cdot 6 \pm 5 \cdot 1$ & $103 \cdot 1 \pm 1 \cdot 5$ & $98.4 \pm 2.5$ & $4 \cdot 1$ & $7 \cdot 3$ \\
\hline 400 & $410 \cdot 5 \pm 4 \cdot 6$ & $397 \cdot 3 \pm 5 \cdot 0$ & $102 \cdot 6 \pm 1 \cdot 2$ & $99 \cdot 3 \pm 1 \cdot 2$ & $3 \cdot 2$ & $3 \cdot 6$ \\
\hline
\end{tabular}

Blood plasma: $r=0.998(y=1.017 x+3 \cdot 266)$

Milk: $r=0.999(y=0.993 x-0.5)$. 
c.p.m./tube) was $87 \cdot 1 \pm 0 \cdot 6 \%(80 \cdot 8-91 \cdot 8 \%)$ for plasma and $65 \cdot 2 \pm 0 \cdot 9 \%(57 \cdot 0-71 \cdot 3 \%)$ for milk. The least amount detected from zero dose was $2.83 \mathrm{pg} /$ tube which was calculated as twice the standard deviation of zero dose tubes. Cross-reaction of the antiserum was obtained by comparing the relative amounts of PGFM and the compounds that were required to reduce the initial binding of $\left[{ }^{3} \mathrm{H}\right] \mathrm{PGFM}$ by $50 \%$ : cross-reactions were $0.79 \%$ for 13,14 -dihydro-PGF- $2 \alpha, 0.27 \%$ for 15 -keto PGF- $2 \alpha, 0.05 \%$ for PGF- $1 \alpha$ and $<0.04 \%$ for PGA-2, PGB-2, PGE- 2 and PGF- $2 \alpha$. The intra-assay coefficient of variation was evaluated by 8 replicate measurements of the same sample in the same assay and was 9.27 and $10.11 \%$ for plasma and milk, respectively. The interassay variation was evaluated by the measurement of the 8 replicates of the same sample in 5 different assays and was 14.4 and $16 \cdot 2 \%$ for plasma and milk, respectively.

\section{Results}

Since the variation in oestrous cycle length was 22-31 days, the results were calculated for the first 17 days after insemination and 4 days before the next oestrus (Tables 2 and 3). Out of 28 animals, 18 animals returned to oestrus and the rest were diagnosed pregnant at 50-60 days after insemination.

Table 2. Mean \pm s.e.m. PGFM concentrations (no. of samples in parentheses) in blood plasma and milk during the oestrous cycle in buffaloes (Day $0=$ day of oestrus)

\begin{tabular}{ccccccc}
\hline \multirow{2}{*}{$\begin{array}{c}\text { Day of } \\
\text { cycle }\end{array}$} & \multicolumn{2}{c}{ PGFM conc. (pg/ml) } & & & \multicolumn{2}{c}{ PGFM conc. (pg/ml) } \\
\cline { 2 - 3 } \cline { 5 - 6 } & Blood & Milk & & $\begin{array}{c}\text { Day of } \\
\text { cycle }\end{array}$ & Blood & Milk \\
\hline 0 & $233 \pm 15(18)$ & $235 \pm 16(18)$ & & 15 & $248 \pm 19(17)$ & $254 \pm 17(17)$ \\
$!$ & $245 \pm 16(17)$ & $229 \pm 15(16)$ & & 17 & $258 \pm 13(17)$ & $262 \pm 17(17)$ \\
3 & $319 \pm 30(17)$ & $257 \pm 18(17)$ & & -4 & $372 \pm 30(18)$ & $429 \pm 16(17)$ \\
5 & $245 \pm 22(15)$ & $256 \pm 16(16)$ & & -3 & $843 \pm 34(17)$ & $692 \pm 35(17)$ \\
7 & $260 \pm 19(16)$ & $274 \pm 16(16)$ & & -2 & $913 \pm 27(16)$ & $792 \pm 32(16)$ \\
9 & $231 \pm 15(17)$ & $240 \pm 11(17)$ & & -1 & $428 \pm 46(15)$ & $445 \pm 42(15)$ \\
11 & $297 \pm 35(17)$ & $254 \pm 13(18)$ & & 0 & $221 \pm 09(18)$ & $248 \pm 12(18)$ \\
13 & $234 \pm 18(17)$ & $238 \pm 11(17)$ & & & \\
\hline
\end{tabular}

Table 3. Mean \pm s.e.m. PGFM concentrations (no. of samples in parentheses) in blood plasma and milk during early pregnancy in buffaloes (Day $0=$ day of insemination)

\begin{tabular}{|c|c|c|c|c|c|}
\hline \multirow{2}{*}{$\begin{array}{c}\text { Day of } \\
\text { pregnancy }\end{array}$} & \multicolumn{2}{|c|}{ PGFM conc. $(\mathrm{pg} / \mathrm{ml})$} & \multirow{2}{*}{$\begin{array}{c}\text { Day of } \\
\text { pregnancy }\end{array}$} & \multicolumn{2}{|c|}{ PGFM conc. $(\mathrm{pg} / \mathrm{ml})$} \\
\hline & Blood & Milk & & Blood & Milk \\
\hline 0 & $244 \pm 23(10)$ & $240 \pm 20(10)$ & 21 & $290 \pm 16(10)$ & $275 \pm 13(10)$ \\
\hline 1 & $242 \pm 28(9)$ & $239 \pm 22(9)$ & 22 & $326 \pm 39(7)$ & $266 \pm 22(9)$ \\
\hline 3 & $326 \pm 26(9)$ & $246 \pm 26(9)$ & 23 & $295 \pm 26(10)$ & $275 \pm 19(10)$ \\
\hline 5 & $271 \pm 22(10)$ & $261 \pm 22(10)$ & 24 & $261 \pm 21(10)$ & $252 \pm 18(10)$ \\
\hline 7 & $267 \pm 29(10)$ & $274 \pm 21(10)$ & 25 & $253 \pm 14(10)$ & $262 \pm 14(10)$ \\
\hline 9 & $259 \pm 18(9)$ & $269 \pm 25(9)$ & 27 & $265 \pm 14(10)$ & $261 \pm 13(9)$ \\
\hline 11 & $278 \pm 26(9)$ & $267 \pm 19(10)$ & 29 & $242 \pm 27(9)$ & $260 \pm 16(10)$ \\
\hline 13 & $240 \pm 17(10)$ & $244 \pm 16(10)$ & 31 & $361 \pm 39(10)$ & $290 \pm 14(10)$ \\
\hline 15 & $250 \pm 15(10)$ & $253 \pm 13(10)$ & 33 & $255 \pm 23(10)$ & $262 \pm 16(9)$ \\
\hline 17 & $249 \pm 23(10)$ & $263 \pm 23(10)$ & 35 & $252 \pm 15(10)$ & $251 \pm 11(10)$ \\
\hline 18 & $277 \pm 18(8)$ & $270 \pm 22(9)$ & 37 & $258 \pm 20(10)$ & $263 \pm 15(10)$ \\
\hline 19 & $273 \pm 21(10)$ & $264 \pm 25(10)$ & 40 & $259 \pm 19(10)$ & $274 \pm 20(9)$ \\
\hline 20 & $272 \pm 17(10)$ & $273 \pm 21(10)$ & & & \\
\hline
\end{tabular}


The PGFM concentration fluctuated around the basal level of $200-250 \mathrm{pg} / \mathrm{ml}$ during the oestrous cycle and started increasing 4 days before oestrus in non-pregnant animals. The temporal changes of PGFM concentration at the time of luteolysis revealed that PGFM concentration fluctuated dramatically, with a major peak occurring $43.83 \pm 1.30 \mathrm{~h}$ before the onset of oestrus (Text-fig. 1).

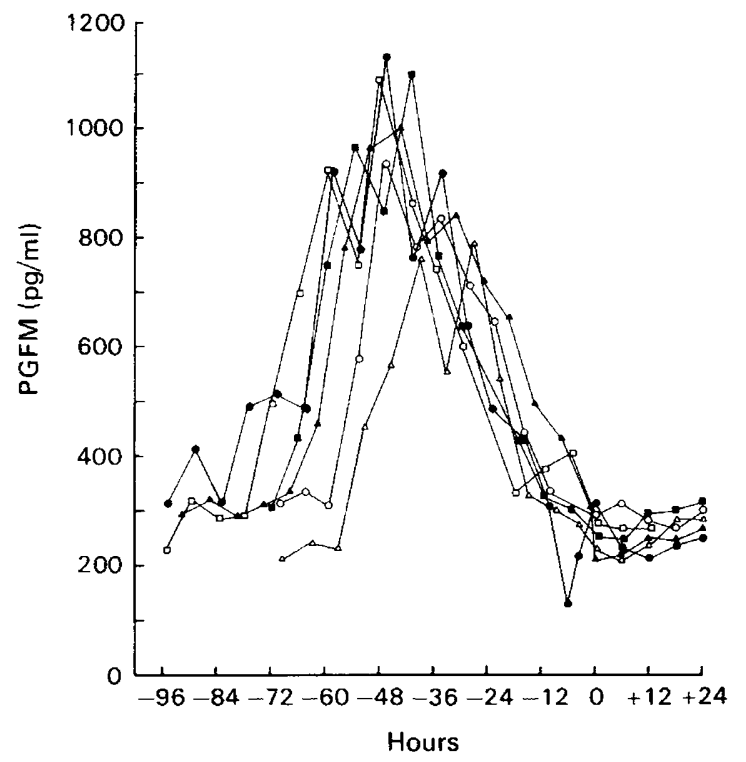

Text-fig. 1. Changes in PGFM concentrations in the blood of buffaloes at the time of oestrus $(0 \mathrm{~h})$.

\section{Discussion}

The basal level of PGFM concentration in peripheral plasma of buffaloes was similar to that reported by Peterson et al. (1975) for cows although Kindahl et al. (1976a) obtained a lower basal level $(50-100 \mathrm{pg} / \mathrm{ml})$. The increase in PGFM concentration before oestrus coincided with the decline of progesterone concentration that is known to occur at this time (Batra et al., 1979; Suri, Batra, Pahwa \& Pandey, 1981; Pahwa \& Pandey, 1982). Since administration of PGF-2 $\alpha$ to buffaloes resulted in the occurrence of oestrus 2-4 days after injection (Prasad, Bachlaus, Arora \& Pandey, 1979), the peak PGFM concentration observed in the present study before oestrus is presumably a reflection of the elevation of endogenous PGF- $2 \alpha$ responsible for regression of the corpus luteum. The temporal changes of PGFM concentration showed a number of peaks before the oestrus, but these peaks were less pronounced than those reported by Kindahl, Edqvist, Granstrom \& Bane (1976b) for cows.

The PGFM concentration did not show any variation during early pregnancy, which agrees with the report of Kindahl et al. (1976b) for cows, and Peterson, Tervit, Fairclough, Havik \& Smith (1976) for ewes. There was no significant difference $(P>0.05)$ in PGFM concentrations in primiparous and multiparous buffaloes.

The level of PGFM in buffalo milk was very similar to that of blood plasma and was positively correlated with it during the oestrous cycle $(r=0.981 ; P<0.001)$ and early pregnancy $(r=0.521$; $P<0.01)$. However, there was no significant difference in the concentration of PGFM $(P>0.05)$ between milk and blood plasma. In the present study, PGFM concentration in milk increased simultaneously with the increase in blood plasma, suggesting the transfer of PGFM into milk down the concentration gradient, but PGFM in milk may also be due to metabolism of PGF- $2 \alpha$ in the mammary gland as reported by Maule Walker \& Peaker (1980) for goats. 
We conclude that because the PGFM level in milk reflects the uterine PGF- $2 \alpha$ concentration, milk PGFM measurements would be a more convenient technique for assessment of some endocrine changes during clinical disorders of buffaloes.

We thank Dr N. H. Dubin and Dr R. Ghodgaonkar, Johns Hopkins University, School of Medicine, Baltimore, Maryland, U.S.A. for the PGFM antiserum; and Ono Pharmaceutical Company, Osaka, Japan for various prostaglandins; Mr G. S. Pahwa and Mr L. V. Rao for help; and the Council of Scientific \& Industrial Research for a Senior Fellowship (S.K.B.).

\section{References}

Bachlaus, N.K., Arora, R.C., Prasad, A. \& Pandey, R.S. (1979) Synchronisation of estrus in buffalo heifers with prostaglandin $\mathrm{F}_{2 \alpha}$, its effect on plasma estrogen and progesterone levels. In Recent Advances in Reproduction and Regulation of Fertility, pp. 149-153. Ed. G. P. Talwar. Elsvier/North Holland Biomedical Press, Amsterdam.

Batra, S.K., Arora, R.C., Bachlaus, N.K. \& Pandey, R.S. (1979) Blood and milk progesterone in pregnant and nonpregnant buffalo. J. Dairy Sci. 62, 1390-1393.

Caldwell, B.V., Tillson, S.A., Brock, W.A. \& Sperofi, L. (1972) The effect of exogenous progesterone and estradiol on prostaglandin $F$ level in ovariectomised ewes. Prostaglandins 1, 217-228.

Dobson, H., Midmer, S.E. \& Fitzpatrick, R.J. (1975) Relationship between progesterone concentrations in milk and plasma during the bovine oestrous cycle. Vet. Rec. 96, 222-223.

Granstrom, E. (1972) On the metabolism of prostaglandin $F_{2 \alpha}$ in female subjects. Structures of two metabolites in blood. Eup. J. Biochem. 27, 462-469.

Kamonpatana, M., Kunawongkrit, A., Bodhipaksha, P. \& Luvira, Y. (1979) Effect of PGF-2 $\alpha$ on serum progesterone levels in swamp buffalo (Bubalus bubalis). J. Reprod. Fert. 56, 445-449.

Kindahl, H., Edqvist, L.E., Bane, L. \& Granstrom, E. (1976a) Blood levels of progesterone and 15-keto13,14 dihydro prostaglandin $F_{2 \alpha}$ during normal oestrous cycle and early pregnancy. Acta endocr., Copenh. 82, 134-149.

Kindahl, H., Edqquist, L.E., Granstrom, E. \& Bane, A. (1976b) The release of prostaglandin $F_{2 \alpha}$ as reffected by 15-keto-13,14 dihydro prostaglandin $F_{2 \alpha}$ in the peripheral circulation during normal luteolysis in heifers. Prostaglandins 11, 871-878.

Lamond, D.R., Tomilson, R.U., Drost, M., Henricks, D.M. \& Jochle, W. (1973) Studies of prostaglandin $\mathrm{F}_{2 \alpha}$ in cow. Prostaglandins 4, 269-283.
Louis, J.M., Hafs, H.D. \& Morrow, D.A. (1972) Estrus and ovulation after uterine $\mathrm{PGF}_{2 \alpha}$ in cow. J. Anim. Sci. 35, 247, Abstr.

Manns, J.G. (1975) The excretion of prostaglandin $F_{2 \alpha}$ in milk of cows. Prostaglandins 9, 463-474.

Maule Walker, F. \& Peaker, M. (1980) Local production of prostaglandins in relation to mammary function at the onset of lactation in goat. $J$. Physiol., Lond. 309, $65-79$.

Pahwa, G.S. \& Pandey, R.S. (1982) Gonadal steroid hormone level in blood plasma and milk of primiparous and multiparous nonpregnant and pregnant buffaloes. Theriogenology (in press).

Peterson, A.J., Fairclough, R.J., Payne, E. \& Smith, J.F. (1975) Hormonal changes around bovine luteolysis. Prostaglandins 10, 675-684.

Peterson, A.J., Tervit, H.R., Fairclough, R.J., Havik, P.G. \& Smith, J.F. (1976) Jugular levels of 13,14 dihydro-15 keto-prostaglandin $F$ and progesterone around luteolysis and early pregnancy in ewes. Prostaglandins 12, 551-557.

Prasad, A., Bachlaus, N.K., Arora, R.C. \& Pandey, R.S. (1979) Synchronisation of oestrus in buffalo heifers with prostaglandin $F_{2 \alpha}$ (Tham-salt) and fertility on AI with frozen semen. Indian J. exp. Biol. 17, 416417.

Rowson, L.E.A., Tervit, R. \& Brand, A. (1972) The use of prostaglandins for synchronisation of oestrus in cattle. J. Reprod. Fert. 29, 145-148.

Samuelsson, B. (1972) Quantitative aspects of prostaglandins synthesis in man. Adv. Biosci. 9, 7-14.

Suri, A.K., Batra, S.K., Pahwa, G.S. \& Pandey, R.S. (1981) Diurnal variations of progesterone in milk of pregnant and nonpregnant buffaloes (Bubalus bubalis). J. Dairy Res. 48, 503-507.

Received 8 June 1982 